\title{
Pendalaman Materi: Laporan Keuangan sebagai Dasar Analisis Investasi Saham
}

\author{
Ika Pratiwi Simbolon'1), Imas Nurani Islami2), Vita Elisa Fitriana ${ }^{3)}$ \\ 1), 2), 3) Fakultas Bisnis, Universitas Presiden \\ 1)ika.pratiwi@president.ac.id \\ 2)imas.islami@president.ac.id \\ 3)vita.elisa@president.ac.id
}

\begin{abstract}
ABSTRAK
Kegiatan pengabdian kepada masyarakat ini bertujuan untuk memperdalam pemahaman masyarakat dalam membuat pencatatan dan pelaporan keuangan secara benar serta menjadikan laporan keuangan tersebut sebagai dasar analisis investasi. Kegiatan ini diperuntukkan bagi siswa-siswi SMK Bina Nasional Informatika, Cikarang Utara. Tahap pelaksanaan kegiatan meliputi survei lapangan, koordinasi dengan kepala sekolah, pelaksanaan program sosialisasi laporan keuangan sebagai dasar analisis investasi saham, dan penyusunan laporan. Kegiatan sosialisasi berjalan dengan lancar dihadiri oleh 28 siswa-siswi Akuntansi kelas XII. Peserta sosialisasi terlihat antusias dengan materi sosialisasi yang diberikan. Hal ini terlihat dari awal hingga akhir acara, semua peserta mengikuti dengan baik. Berdasarkan hasil wawancara, tanya jawab dan pengamatan langsung, kegiatan pengabdian kepada masyarakat ini telah meningkatkan pengetahuan para siswa-siswi sebanyak $80 \%$ mengenai penyusunan laporan keuangan yang baik dan melakukan valuasi saham berdasarkan laporan keuangan.
\end{abstract}

Kata-kata Kunci: Discounted Cash Flow Model, Investasi, Laporan Keuangan, Saham

\section{ABSTRACT}

This community service activities aims to deepen public understanding in making financial records and reporting correctly and making the financial statements as a basis for investment analysi. The investment analysis method used is a discounted cash flow model to determine whether the investment is undervalued or overvalued. The community in this activity are students of SMK Bina Nasional Informatika, North Cikarang. The implementation phase of this activity includes a field survey, coordination with the school principal, the implementation of a financial report socialization program as a basis for stock investment analysis, and preparation of the report. The socialization activity went smoothly attended by 28 Accounting students in class XII. Socialization participants seemed enthusiastic about the material provided. This can be seen from the beginning to the end of the event, all participants followed well. Based on the results of interviews, questions and answers and direct observations, community service activities have increased the knowledge of students by as much as $80 \%$ about how to prepare good financial statements and conduct stock valuations using financial statements.

Keywords: Discounted Cash Flow Model, Investment, Financial Statements, Stocks

\section{PENDAHULUAN}

Investasi di Indonesia yang semakin meningkat mendorong para investor dalam memperdalam pemahaman mengenai investasi. Investasi adalah komitmen atas sejumlah dana untuk tujuan memperoleh keuntungan di masa mendatang (Jogiyanto, 2012). Saham adalah salah satu jenis investasi di pasar modal. Saham merupakan surat kepemilikan atas asset suatu perusahaan (Tandelilin, 2001).

Statistik pasar modal yang dikeluarkan oleh situs Otoritas Jasa Keuangan menggambarkan trend peningkatan Indeks Harga Saham Gabungan (IHSG) dan nilai rata- 
rata perdagangan harian per bulan dari tahun 2013 sampai dengan Mei 2018 (Gambar 1). Oleh sebab itu, investasi saham merupakan investasi yang cukup diminati.

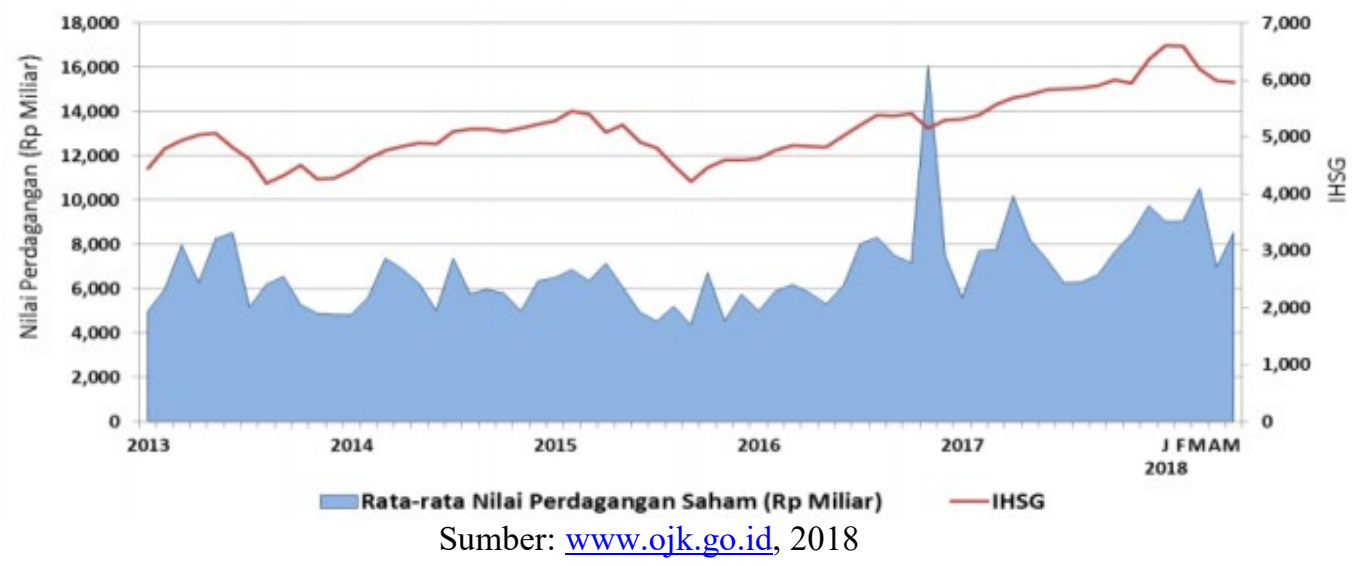

Gambar 1.

IHSG dan Nilai Rata-rata Perdagangan Harian per Bulan, 2013-11 Mei 2018

Tujuan utama investor dalam melakukan investasi adalah memperoleh profit atau tingkat pengembalian. Tingkat pengembalian merupakan imbalan atas keputusan investor dalam menanggung risiko atas suatu investasi (Tandelilin, 2001). Dalam bidang investasi saham, profit tersebut dapat diperoleh dalam dua bentuk, yaitu capital gain dan dividen. Capital gain dapat diperoleh dari selisih harga jual saham yang lebih tinggi daripada harga beli saham itu sendiri, sedangkan dividen dapat diperoleh investor melalui pembagian laba berdasarkan jumlah saham yang dimiliki. Untuk memastikan bahwa investasi yang dilakukan dapat memberikan profit, investor harus menentukan perusahaan mana yang dapat memberikan keuangan dan perusahaan mana yang justru akan memberikan kerugian.

Keputusan investasi sendiri harus dilakukan dengan analisis terentu, sehingga dapat dilakukan investasi secara tepat. Salah satu analisis tersebut berupa analisis fundamental, yaitu analisis yang didasarkan pada laporan keuangan perusahaan. Dalam laporan keuangan perusahaan memuat informasi mengenai keadaan dan kondisi perekenomian, yang tercermin dalam laporan laba-rugi, laporan perubahan ekuitas, laporan posisi keuangan, laporan arus kas, serta catatan atas laporan keuangan (Weygant, Kimmel, \& Kieso, 2015). Tiap-tiap jenis laporan tersebut mengandung informasi yang bermanfaat bagi pengguna laporan keungan.

Jika ditinjau dari sisi internal perusahaan, laporan keuangan perusahaan merupakan bentuk pertanggungjawaban manajemen atas pengelolaan perusahaan terhadap pemilik. Untuk menghasilkan laporan tersebut, diperlukan serangkaian proses yang harus dilaksanakan secara cermat agar nantinya, laporan kekuangan mencerminkan informasi yang sebenar-benarnya. Serangkaian proses tersebut terangkum dalam tiga proses utama 
yang dimulai dari pengidentifikasian, pencatatan, hingga pengkomunikasian laporan keuangan (Weygant, et al., 2015). Pengkomunikasian yang dimaksudkan tersebut dilakukan dengan menggunakan laporan keuangan perusahaan.

Dalam melakukan kegiatan investasi saham, investor harus mengetahui nilai intrinsik dari suatu saham dengan menggunakan laporan keuangan tersebut. Nilai intrinsik saham yang telah diketahui dapat membantu investor dalam membuat keputusan membeli atau menjual tersebut. Investor sebaiknya membeli undervalued stock dan menjual overvalued stock. Undervalued stock merupakan saham yang memiliki nilai pasar lebih rendah daripada nilai intrinsik, sehingga saham tersebut layak untuk dibeli. Sedangkan overvalued stock merupakan saham yang memiliki nilai pasar lebih tinggi daripada nilai intrinsik saham tersebut, sehingga saham tersebut layak untuk dijual.

Valuasi nilai intrinsik saham di dalam kegiatan sosialisasi ini adalah menggunakan discounted cash flow model. Penelitian mengenai valuasi saham menggunakan discounted cash flow model mengalami perkembangan yang cukup signifikan. Terdapat perbedaan hasil penelitian untuk metode yang paling tepat dalam valuasi saham yang cocok untuk negara dengan ekonomi berkembang. Pereiro (2006) mengemukakan jika discounted cash flow model sama seperti Net Present Value, Interest Rate Return dan Payback Period adalah metode yang sama baiknya dan digunakan di antara banyak perusahaan dan penasehat keuangan. Ivanovska, Ivanovski dan Narasanov (2014) menemukan discounted cash flow model memiliki hasil valuasi nilai saham yang mendekati rata-rata harga pasar untuk perusahaan yang diprediksi dalam jangka panjang.

Dosen Program Studi Akuntansi Universitas Presiden melakukan pendekatan dalam peningkatan kesadaran warga Indonesia terhadap investasi saham. Valuasi investasi saham di pasar modal dengan pendalaman laporan keuangan kegiatan menjadi topik dalam sosialisasi ini. Sekolah Menengah Kejuruan (SMK) merupakan peserta yang akan menghadiri sosialisasi ini. Siswa-siswi SMK diharapkan menjadi calon investor, sehingga harus memahami dengan baik peranan investasi itu sendiri terhadap pembangunan suatu negara dan juga kesejahteraan yang akan diperoleh nantinya.

Berdasarkan latar belakang ini, maka para dosen Program Studi Akuntansi Universitas Presiden tertarik untuk melakukan sosialisasi kepada siswa-siswi di SMK Bina Nasional Informatika, Cikarang Utara. Tujuan dari kegiatan sosialisasi ini adalah untuk memperdalam pemahaman siswa dalam membuat pencatatan dan pelaporan keuangan secara benar serta menjadikan laporan keuangan tersebut sebagai dasar analisis investasi melalui laporan keuangan. Pengembangan tingkat pengetahuan masyarakat tentang valuasi saham dan laporan keuangan inilah salah satu cara dalam meningkatkan kesadaran masyarakat untuk melakukan investasi di pasar modal Indonesia. 


\section{METODE KEGIATAN}

Kegiatan sosialisasi ini dilaksanakan di SMK Bina Nasional Informatika, Cikarang. Peserta dalam kegiatan ini adalah siswa Jurusan Akuntansi Kelas XII. Kegiatan sosialiasi ini terbagi menjadi 4 sesi, sebagai berikut:

\section{a. Sesi Pertama}

Sesi pertama adalah pembukaan dilanjutkan dengan penjelasan mengenai tujuan diselenggarakannya Kegiatan Pengabdian kepada Masyarakat di di SMK Bina Nasional Informatika, Cikarang. Tahap ini bertujuan untuk memberikan pemahaman kepada siswasiswi akuntansi di di SMK Bina Nasional Informatika, Cikarang Utara tentang pentingnya memahami laporan keuangan sebagai dasar analisis untuk berinvestasi. Makna kegiatan pengabdian kepada masyarakat juga ditekankan di tahap ini.

\section{b. Sesi Kedua}

Sesi kedua adalah program sosialisasi pencatatan transaksi keuangan dan pembuatan laporan keuangan. Materi tersebut dipresentasikan oleh Imas Nurani Islami, S.Pd., M.Sc. dan Vita Elisa Fitriana, SE., M.Sc. Pada tahap ini penyaji membahas pentingnya memahami siklus akuntansi dan bagaimana cara melakukan pencatatan dan pembuatan laporan keuangan yang benar.

\section{c. Sesi Ketiga}

Sesi ketiga adalah program sosialisasi yang berkaitan dengan investasi dalam bentuk saham. Materi tersebut akan dipresentasikan oleh Dr. Ika Pratiwi Simbolon, S.E., M.M. Pada tahap ini penyaji akan membahas pentingnya berinvestasi dan bagaimana cara berinvestasi dalam bentuk saham.

\section{d. Sesi Keempat}

Sesi keempat adalah tanya jawab dalam pengukuran pemahaman siswa-siswi terhadap kegiatan sosialisasi.

Jadwal kegiatan pengabdian kepada masyarakat di SMK Bina Nasional Informatika ini adalah sebagaimana terlihat pada Tabel 1 , dengan penjelasan sebagai berikut:

\section{a. Survei lapangan}

Survei lapangan bertujuan untuk mengamati situasi dan keadaan sekolah yang direncanakan sebagai objek sasaran. 


\section{b. Koordinasi dengan kepala sekolah}

Berkoordinasi dengan kepala sekolah untuk menentukan kesepakatan mufakat antara pelaksana program pengabdian masyarakat dengan kepala sekolah di SMK Bina Nasional Informatika, Cikarang.

\section{c. Pelaksanaan Program}

Pelaksanaan sosialisasi ini akan dilakukan di di SMK Bina Nasional Informatika, Cikarang. Sosialisasi ini akan melibatkan beberapa pihak, di antaranya adalah guru, kepala sekolah, kalangan akademisi serta warga sekitar. Di dalam sosialisasi ini akan menghadirkan 3 narasumber di antaranya adalah Dr. Ika Pratiwi Simbolon, SE., M.M, Imas Nurani Islami, S.Pd., M.Sc, dan Vita Elisa Fitriana, S.E., M.Sc. Setelah dilakukan sosialisasi, tahap selanjutnya terdapat sesi tanya jawab untuk mengevaluasi berapa persen pemahaman peserta terhadap materi yang telah diberikan.

\section{d. Penyusunan Laporan}

Mengevaluasi perkembangan pelaksanaan program yang dilaksanakan untuk siswasiswi SMK dengan dituangkan dalam sebuah laporan.

Tabel 1. Jadwal kegiatan

\begin{tabular}{|l|l|l|l|l|}
\hline \multicolumn{1}{|c|}{ Deskripsi Kegiatan } & \multicolumn{3}{c|}{ Bulan } \\
\cline { 2 - 5 } & Minggu 1 & Minggu 2 & Minggu 3 & Minggu 4 \\
\hline $\begin{array}{l}\text { Survei lapangan dan surat permohonan } \\
\text { pelaksanaan program }\end{array}$ & & & & \\
\hline Persiapan perlengkapan program & & & & \\
\hline $\begin{array}{l}\text { Proses pelaksanaan sosialisasi ke siswa- } \\
\text { siswi di SMK Bina Nasional Informatika, } \\
\text { Cikarang. }\end{array}$ & & & \\
\hline Penyusunan laporan & & & & \\
\hline
\end{tabular}

\section{HASIL DAN PEMBAHASAN}

\subsection{Siklus Akuntansi}

Siklus akuntansi merupakan serangkaian tahap untuk menghasilkan informasi akuntansi yang dapat dipergunakan oleh pihak-pihak yang berkepentingan (Weygant et al., 2015). Gambar 2 merupakan bagan siklus akuntansi.

Tahap-tahap pada siklus akuntansi di antaranya (Weygant et al., 2015):

\section{a. Identifikasi Transaksi}

Tahap pertama adalah mengidentifikasi transaksi apa saja yang telah berlangsung selama periode tersebut. Sumber dokumen seperti kwitansi, faktur penjualan, faktur pembelian, penerimaan kas, kartu jam kerja dan yang lainnya. 


\section{b. Membuat Jurnal}

Tahap kedua adalah Jurnal. Jurnal merupakan proses pencatatan transaksi perusahaan berdasarkan sumber dokumen.

\section{c. Memindahbukukan (Posting) Transaksi Akuntansi dari Jurnal ke Buku Besar}

Tahap ketiga adalah Posting. Posting adalah aktivitas memindahkan catatan dari buku jurnal ke dalam dalam buku besar sesuai dengan jenis transaksi dan nama perkiraan masing-masing.

\section{d. Menyusun Neraca Saldo}

Tahap keempat adalah mebuat neraca saldo. Neraca Saldo berisi daftar akun-akun yang digunakan beserta nilai saldonya. Fungsi neraca saldo yaitu untuk membuktikan bahwa sisi debit dan kredit telah balance (transaksi akuntansi telah dicatat dan dibukukan).

e. Membuat Jurnal Penyesuaian dan Membukukan (Posting) Jurnal Penyesuaian ke Buku Besar

Jurnal penyesuaian dilakukan apabila ada kesalahan pada penjurnalan dan posting atau memastikan biaya dan pendapatan benar-benar telah dicatat pada periode yang benar.

\section{f. Menyusun Neraca Saldo Setelah Penyesuaian}

Neraca saldo setelah penyesuaian akan dijadikan sebagai dasar untuk menyusun laporan keuangan. Setelah disusun ayat penyesuaian atas akun-akun tertentu, akun-akun yang bersangkutan tersebut pasti mengalami perubahan nilai atau nominal, sehingga nilai saldonya perlu disesuaikan kembali dengan menyusun neraca saldo setelah penyesuaian.

\section{g. Menyusun Laporan Keuangan}

Laporan keuangan secara umum meliputi, laporan laba/rugi, laporan perubahan modal, dan neraca. Pada tahap ini akun-akun yang ada pada neraca saldo setelah penyesuaian dipindahkan ke laporan keuangan sesuai dengan laporan keuangannya.

1) Laporan Neraca

Laporan neraca adalah laporan yang berisi posisi keuangan perusahaan meliputi aset, utang, dan modal pada periode akuntansi tertentu.

2) Laporan Laba Rugi

Laporan laba rugi adalah laporan yang menyajikan perhitungan atas semua pendapatan dan biaya perusahaan.

3) Laporan Perubahan Modal 
Laporan perubahan modal adalah laporan yang menyajikan perubahan posisi modal perusahaan. Perubahan tersebut terjadi karena penambahan (tambahan modal disetor) atau pengurangan investasi (prive) dari pemilik modal perusahaan. Kemudian hasilnya ditambah dengan laba atau dikurangi rugi perusahaan dari laporan laba rugi. Hasilnya, dapat diketahui berapa jumlah modal perusahaan pada akhir periode akuntansi.

\section{4) Laporan Arus Kas}

Laporan arus kas adalah laporan yang menyajikan aliran dana kas masuk dan keluar perusahaan pada aktivitas investasi, operasional, dan pendanaan dalam satu periode akuntansi tertentu.

\section{5) Catatan Atas Laporan Keuangan}

Catatan atas laporan keuangan yaitu laporan tambahan yang berisi informasi yang lebih rinci atas akun tertentu. Tujuannya adalah untuk memberikan nilai yang lebih komprehensif atas laporan keuangan perusahaan. Dalam catatan ini, biasanya terdapat informasi metode pencatatan akuntansi yang digunakan.

\section{h. Membuat Jurnal Penutup dan Membukukan (Posting) Jurnal Penutup ke Buku Besar}

Membuat jurnal untuk menutup semua akun yang berkaitan dengan laporan laba rugi dan laporan perubahan modal. Tujuan jurnal penutup ini adalah menghindari terjadinya perhitungan ulang pada periode akuntansi berikutnya. Jadi, yang ditutup meliputi akun-akun pendapatan, beban dan perubahan modal.

\section{i. Menyusun Neraca Saldo Setelah Penutupan}

Tujuan dari neraca ini adalah untuk melihat apakah akun telah seimbang (balance) untuk selanjutnya memulai kegiatan akuntansi pada periode baru. Teknisnya dengan menyusun akun-akun yang masih memiliki nilai saldo setelah dilakukan penutupan. 


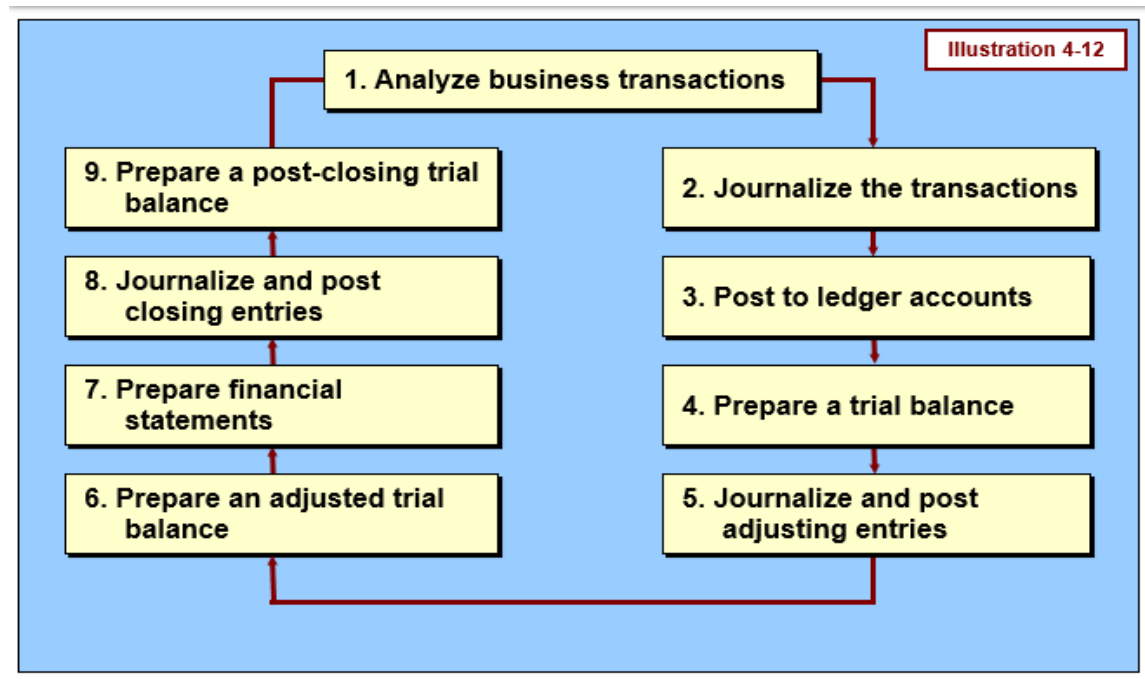

Sumber: Weygant et al., 2015

Gambar 2. Siklus Akuntansi

\subsection{Investasi}

Investasi adalah komitmen atas sejumlah dana atau sumber daya lain dengan tujuan mendapatkan keuntungan di masa yang akan dating (Tandelilin, 2001). Dalam sudut pandang keuangan, investasi ini termasuk pembelian obligasi, saham atau properti. Selain itu, bangunan yang dibangun atau fasilitas lain yang digunakan untuk memproduksi barang dapat dilihat sebagai investasi. Produksi barang yang dibutuhkan untuk memproduksi barang lain juga dapat dilihat sebagai investasi.

Investasi yang akan dibahas dalam kegiatan ini adalah investasi saham. Terdapat dua jenis saham, common stock dan preferred stock. Common stock biasanya memberikan hak kepada pemilik untuk memilih pada rapat pemegang saham dan untuk menerima dividen. Pemegang preferred stock umumnya tidak memiliki hak suara, tetapi memiliki klaim yang lebih tinggi atas aset dan pendapatan daripada saham biasa. Sebagai contoh, pemegang preferred stock menerima dividen sebelum pemegang common stock dan memiliki prioritas dalam hal perusahaan bangkrut dan dilikuidasi.

\subsection{Valuasi Saham}

Undervalued stock adalah saham yang diyakini harganya terlalu rendah berdasarkan indikator saat ini, seperti yang digunakan dalam model valuasi. Jika saham perusahaan tertentu dinilai jauh di bawah rata-rata industri, itu dapat dianggap undervalued. Sebaliknya overvalued stock adalah saham yang diyakini harganya terlalu tinggi berdasarkan indikator saat ini, seperti yang digunakan dalam model valuasi.

Discounted Cash Flow Model akan digunakan dalam valuasi saham untuk menentukan saham tersebut undervalued atau overvalued. Valuasi saham menggunakan valuasi Discounted Cash Flow Model adalah valuasi dengan kalkulasi present value dari free 
cash flow yang diproyeksikan (Penman, 2013). Berikut terdapat perhitungan nilai sebuah perusahaan dengan menggunakan Discounted Cash Flow Model (Penman, 2013):

$$
\text { Value of the firm }=\frac{C_{1}-I_{1}}{(1+r)^{1}}+\frac{C_{2}-I_{2}}{(1+r)^{2}}+\frac{C_{3}-I_{3}}{(1+r)^{3}}+\cdots
$$

\section{Keterangan: \\ $\mathrm{C}=$ cash from operations \\ $\mathrm{I}=$ cash from investments \\ $r=$ rate of return}

Berikut terdapat valuasi saham dengan menggunakan Discounted Cash Flow Model (Tabel 2).

Tabel 2.

Discounted Cash Flow Model

\begin{tabular}{|l|c|c|c|c|c|c|}
\hline & $\mathbf{2 0 1 2}$ & $\mathbf{2 0 1 3}$ & $\mathbf{2 0 1 4}$ & $\mathbf{2 0 1 5}$ & $\mathbf{2 0 1 6}$ & $\mathbf{2 0 1 7}$ \\
\hline $\begin{array}{l}\text { Cash from } \\
\text { operations }\end{array}$ & 3.500 & 4.100 & 4.400 & 5.010 & 5.500 & 6.600 \\
\hline Cash investments & 1.000 & 1.010 & 9.80 & 880 & 780 & 700 \\
\hline Free cash flow & 2.500 & 3.090 & 3.420 & 4.130 & 4.720 & 5.900 \\
\hline $\begin{array}{l}\text { Discount rate } \\
(1.09)^{\mathrm{t}}\end{array}$ & 1,09 & 1,18 & 1,29 & 1,41 & 1,53 & 1,67 \\
\hline $\begin{array}{l}\text { Present value of } \\
\text { free cash flows }\end{array}$ & $2.293,57$ & $2.600,79$ & $2.640,87$ & $2.925,79$ & $3.067,67$ & $3.517,98$ \\
\hline
\end{tabular}

Total present value to $2017=17.046,6862$. Jika saham yang beredar $=2.200$ dan harga saham saat ini $=\$ 15,22$. Maka value of equity $=17.046,6862 / 2 \cdot 200=\$ 7,74$. Saham ini termasuk undervalued stock, sebaiknya saham ini segera dibeli dikarenakan intrinsic value lebih tinggi daripada nilai pasar saat ini.

\section{KESIMPULAN}

Kegiatan sosialisasi laporan keuangan sebagai dasar analisis investasi saham sudah dilakukan terhadap siswa-siswi SMK Bina Nasional Informatika, Cikarang Utara. Tanggal dan waktu pelaksanaaan dilakukan pada tanggal 18 Januari 2019 pada pukul 07.00 sampai dengan 10.00. Kegiatan sosialisasi berjalan dengan lancar dihadiri oleh 28 siswa-siswi Akuntansi kelas XII. Peserta sosialisasi terlihat antusias dengan materi pelatihan yang diberikan. Hal ini terlihat dari awal hingga akhir acara, semua peserta mengikuti dengan baik.

Berdasarkan hasil wawancara, tanya jawab dan pengamatan langsung, kegiatan pengabdian kepada masyarakat ini telah meningkatkan pengetahuan para siswa-siswi sebanyak $80 \%$ mengenai bagaimana melakukan valuasi saham. 
Faktor pendukung terlaksananya kegiatan pengabdian kepada masyarakat ini adalah antusiasme siswa-siswi yang cukup tinggi selama kegiatan, sehingga kegiatan berlangsung dengan cukup lancar dan efektif. Sedangkan faktor penghambatnya adalah keterbatasan waktu untuk merealisasikan program pengabdian kepada masyarakat ini.

\section{REFERENSI}

Ivanovska, N., Ivanovski, Z., \& Narasanov, Z. (2014). Fundamental Analysis and Discounted Free Cash Flow Valuation of Stocks at Macedonian Stock Exchange. UTMS Journal of Economics, 5(1), 11-24.

Jogiyanto. (2012). Teori Portofolio dan Analisis Investasi Edisi Tiga. Cetakan Tujuh. Jogjakarta: BPFE.

Penman, S., H. (2013). Financial Statement Analysis and Security Valuation. Fifth Edition. New York: McGraw-Hill.

Pereiro. L. (2006). The Practice of Investment Valuation in Emerging Markets: Evidence from Argentina. Journal of Multinational Financial Management, 16, 60-183.

Tandelilin, E.. (2001). Analisis Investasi dan Manajemen Portofolio. Yogyakarta: BPFE Yogyakarta.

Weygant, J. J., Kimmel, P. D., \& Kieso, D. E. (2015), Financial Accounting: IFRS, $3^{\text {rd }}$ Ed. New Jersey: John Wiley \& Sons.

www.ojk.go.id. (2018). Grafik IHSG dan Nilai Rata-rata Perdagangan Harianper Bulan 2013-11 Mei 2018 